Article

\title{
Analysis of Driving Factors for Extended Producer Responsibility by Using Interpretative Structure Modelling (ISM) and Analytic Network Process (ANP)
}

\author{
Xiong Zheng, Fangchao $\mathrm{Xu}$ * and Lipan Feng \\ Business School, Nankai University, Tianjin 300071, China; xzheng79@163.com (X.Z.); hnnuflp@163.com (L.F.) \\ * Correspondence: xufc@mail.nankai.edu.cn \\ Academic Editors: Sang-Bing Tsai, Bin Liu, Joseph Z. Shyu, Yong Deng, Ming-Lang Tseng and Jih-Jeng Huang \\ Received: 21 December 2016; Accepted: 28 March 2017; Published: 31 March 2017
}

\begin{abstract}
The establishment of an efficient reverse supply chain is important, especially in the electronics industry, considering the environmental and resource pressures worldwide. Extended Producer Responsibility (EPR), an important environmental policy approach, has been adopted extensively in various countries, and the effectiveness of its implementation has been proven through practical application. However, the establishment and development of EPR are lacking in most developing countries where collection and recycling systems are underdeveloped. This study addresses this problem by exploring the hierarchical relationship among the driving factors of EPR in the electronics industry in China and by identifying and ranking the factors that are critical in EPR implementation. As important managerial conclusions, research results show that EPR-related laws and regulations, the consciousness of senior executives, and corporate image are the three most important driving factors of EPR implementation.
\end{abstract}

Keywords: Extended Producer Responsibility; driving factors; Interpretative Structure Modelling; Analytic Network Process

\section{Introduction}

Rapid economic development has improved the level of the national economy but has gravely damaged the environment. Achieving sustainable development by protecting the environment whilst maintaining economic development, has become an imminent task. Extended Producer Responsibility (EPR), which means that the responsibility of a producer is extended to the post-consumer stage of the product life cycle, has been extensively implemented in waste electrical and electronic equipment (WEEE)-related laws and regulations in various countries (Organisation for Economic Co-operation and Development or OECD [1]. Many countries have exerted considerable effort on EPR legislation and implementation to minimise environmental pollution and encourage producers to assume the extended responsibilities of collecting, recycling, remanufacturing, and product designing for the environment. EPR programmes involve various policy instruments, such as fees, subsidies, bans/restrictions, permits, targets, standards, labels, and information campaigns (Manomaivibool [2]). EPR is also effective in WEEE management in many developed countries. Relatively mature systems of EPR have been established and enforced in several European countries, such as Germany and Denmark, and manufacturers implement EPR under the corresponding EPR regulation.

However, the implementation situation and progress of EPR in developing countries are less satisfactory than those in developed countries. Moreover, most developing countries face extreme pressure in terms of WEEE recycling due to increasing industrialisation, although the collection and 
recycling systems in developing countries are immature. For example, China has become the largest 'manufacturing plant' in the world. China also possesses the largest consumer group in the world and generates a large amount of waste products. A report from the World Bank indicates that China is the largest producer of solid waste in the world and that the waste of electronic products has become a serious social and environmental threat. Some research data indicate that China's electronic waste amounted to 2212 thousand tons in 2007, and the sum increased to 3300 thousand tons in 2010 with an annual growth rate of $19.9 \%$. Therefore, EPR implementation in developing countries is extremely urgent, and governments and nongovernmental organisations (NGOs) should adopt measures to improve the spread and implementation of EPR. From this aspect, identifying the driving factors of EPR is crucial.

Increased awareness and growing environmental concerns about the disastrous effects on the environment and natural resources have prompted businesses and governments to reconsider their strategy for growth and economic development. For governments, laws and regulations are the most efficient governance tools to prompt EPR. Such laws and regulations include the WEEE Directive (European Union), Home Appliance Recycling Law (Japan), Act for Resource Recycling of Electrical/Electronic Products and Automobiles (Korea), and Regulation on the Administration of the Recovery and Disposal of Waste Electrical and Electronic Products (China). Aside from the pressure from governments and regulations, intense global competition and consumer preference also force producers to implement EPR in their commercial practice. The green barrier is a great challenge in trade and sales in the overseas market, especially for enterprises in developing countries. Huawei, a famous mobile phone manufacturer, has to carry out EPR because it aims to enter European and American markets. In western countries, consumers are usually sensitive to WEEE product recycling when they purchase new products, and this scenario encourages manufacturers to pay more attention to EPR. This phenomenon has resulted in increased efforts in collection system establishment, recycling technology improvement, EPR implementation in European countries, and EPR expansion to other countries.

The introduction and commercial cases provided above imply that factors from several perspectives play vital roles in the promotion of EPR in a certain country or area, and the driving factors may differ in different countries. This study aims to investigate the driving factors of EPR implementation and identify the dominant factors amongst all of the driving factors in China. A few suggestions and guidelines on EPR implementation in the electronics industry are provided. As important managerial conclusions, the research results show that EPR-related laws and regulations, the consciousness of senior executives, and corporate image are the three most important driving factors of EPR implementation. The findings provide a theoretical foundation for EPR implementation for governments. With regard to the research methodology, this study combines Interpretative Structure Modelling (ISM) and Analytic Network Process (ANP). Each method is utilised to explore the driving factors of EPR. ISM is used to explore the hierarchical relationships amongst the driving factors of EPR, and ANP is used to rank the driving factors according to their respective weights. ISM plays a crucial role in exploring the hierarchical relationships amongst the driving factors of EPR and provides the input of relationships for ANP analysis, which ranks the driving factors according to their respective weights and identifies the factors that are critical in EPR implementation.

The remainder of this paper is organised as follows. Section 2 provides a review of relevant literature. Section 3 presents the research problem and identifies certain driving factors. Sections 4 and 5 present the analysis of driving factors through ANP and ISM. Section 6 provides several important conclusions and insights to serve as guidelines for EPR implementation. 


\section{Literature Review}

\subsection{Theory and Practice Research of Extended Producer Responsibility}

EPR was proposed and defined by Lindhqvist as follows: 'EPR is a policy principle to promote total life cycle environmental improvements of product systems by extending the responsibilities of the manufacturer of the product to various parts of the product's lifecycle, and especially to the takeback, recovery, and final disposal of the product' (Lindhqvist, [3]). Following this definition, many scholars and research institutions have conducted numerous theoretical and practical studies on this policy. From the perspective of theory, OECD [1], Kibert [4] (2004), Lifset et al. [5], and Kiddee et al. [6] thoroughly discussed the meaning of EPR. OECD [1] provided an overview of key issues, such as general considerations and the potential benefits and costs associated with producers' responsibility to manage the waste generated by their products in the market. With the theoretical research on EPR, scholars have focused on the combination of EPR theory and operation mechanism. OECD [7] provided updated guidance on the design of EPR by analysing selected cases and discussing certain challenges faced by several developing countries in terms of their EPR implementation. Nash and Bosso [8] described the evolution of EPR policies in the United States, specifically the role of states as policy actors. Kunz et al. [9] provided an overview of the stakeholders in EPR from the perspective of a complete system; the involvement and the evolution of the roles of the stakeholders in EPR implementation were examined. The stakeholders included producers, producer responsibility organisations, waste operators, national authorities, municipalities, trade associations, clearing houses/national registers, retailers, environmental and consumer NGOs, the European Commission, the illegal informal sector, and communities. Gui et al. [10] provided an overview of various stakeholder perspectives and their implications on attaining EPR policy objectives in practice. The authors presented recommendations on how to achieve an effective and efficient EPR implementation. These recommendations included the improvement of design incentives, incorporation of reuse and refurbishing, expansion of the product scope, management of downstream material flows and promotion of operational efficiency via a fair cost allocation design. Wang and Chen [11] analysed the current recycling system of end-of-life vehicles in China and introduced an automotive product recycling technology roadmap as well as the recycling industry development goals.

\subsection{Driving Factor Analysis of Extended Producer Responsibility}

Several scholars have conducted research on the driving factors of EPR in several industries in different countries. Toffel [12] reviewed previous academic research on end-of-life (EOL) product recovery, which is a component of EPR, and found that non-market and market pressures drive companies to take responsibility for their EOL products. Zhu et al. [13] conducted empirical research on the main factors that influence EPR implementation in the automobile industry in China and found multiple effects of economy, technology, consciousness, international trade, laws and regulations, government management, and other factors. Gupt and Sahay [14] conducted an exploratory review of 27 cases of EPR in developed and developing economies with and without informal recycling; they used exploratory factor analysis to determine 13 variables in the primary aspects of EPR implementation. The study identified regulatory provisions, take-back responsibility, and financial flow as the most significant aspects of EPR. Wang and Chen [15] explored EPR implementation in vehicle remanufacturing in China. The large market of vehicles, strong support from the Chinese government, and late-development advantage significantly promote the effective remanufacturing processes of automotive parts. Moreover, Manomaivibool [2] conducted a case study to analyse the drivers and barriers in applying EPR in non-OECD countries and found that large grey markets for electronic products and illegal imports of WEEE are the two main barriers in EPR implementation in India. Specific to the EPR implementation in China, Tong et al. [16] analysed diverse incentives to adopt EPR in countries in developed and developing countries, and they pointed out that the incentives for China to adopt EPR in e-waste management are quite different from those in the developed countries. 
Focusing on the exploration of the driving factors of EPR, most extant studies adopted theoretical analysis, the empirical method, and the case study method to identify the driving factors. Meanwhile, the hierarchical structure and the relationships amongst driving factors have not been studied. The current research is the first to explore the hierarchical structure of the driving factors of EPR through ISM. We obtained the cause-and-effect relationships amongst the driving factors and identified the most fundamental driving factors. Compared with extant research that identified the driving factors of EPR, we creatively considered several new driving factors, such as support of financing institutions, as shown in Table 1.

Table 1. List of Driving Factors for Extended Producer Responsibility (EPR).

\begin{tabular}{|c|c|c|c|}
\hline $\begin{array}{c}\text { Serial } \\
\text { Number }\end{array}$ & Driving Factors & Explanations & Sources \\
\hline 1 & $\begin{array}{l}\text { EPR-related Laws } \\
\text { and Regulations }\end{array}$ & $\begin{array}{l}\text { Laws and regulations are the } \\
\text { instruments necessary for governance } \\
\text { of business enterprises. EPR-related } \\
\text { laws and regulations play an important } \\
\text { role in EPR implementation } \\
\text { of companies. }\end{array}$ & $\begin{array}{l}\text { Zhu \& Sarkis [17]; } \\
\text { Alkhidir \& Zailani [18]; } \\
\text { Wu et al. [19]; } \\
\text { Diabat \& Govindan [20] }\end{array}$ \\
\hline 2 & $\begin{array}{l}\text { Mimetic Pressure } \\
\text { from Competitors }\end{array}$ & $\begin{array}{l}\text { Enterprises whose competitors } \\
\text { implement EPR widely need to keep } \\
\text { themselves ahead of others. }\end{array}$ & $\begin{array}{l}\text { Luo et al. [21]; } \\
\text { Lilly [22]; } \\
\text { Gutowasky et al. [23]; }\end{array}$ \\
\hline 3 & $\begin{array}{l}\text { Promotion and Activity of } \\
\text { Nongovernmental } \\
\text { Organisations }\end{array}$ & $\begin{array}{l}\text { Some promotion activities of e-NGOs } \\
\text { promote the implementation of EPR. }\end{array}$ & $\begin{array}{l}\text { Zhu \& Sarkis [17]; } \\
\text { Zhu et al. [24] }\end{array}$ \\
\hline 4 & $\begin{array}{l}\text { Support of Financing } \\
\text { Institutions }\end{array}$ & $\begin{array}{l}\text { Green finance provided by financing } \\
\text { institutions to green enterprises } \\
\text { encourages enterprises to } \\
\text { implement EPR. }\end{array}$ & Our contributed barrier \\
\hline 5 & Pressure from Consumers & $\begin{array}{l}\text { The concern of customers for } \\
\text { environment is one of influencing } \\
\text { factors of EPR. }\end{array}$ & $\begin{array}{l}\text { Rehman \& Shrivastava [25], } \\
\text { Soo and Quazi [26]; } \\
\text { Sarkis [27]; } \\
\text { Berry and Rondinelli [28] }\end{array}$ \\
\hline 6 & $\begin{array}{l}\text { Opportunity in the } \\
\text { New Market }\end{array}$ & $\begin{array}{l}\text { EPR implementation creates significant } \\
\text { market increase in customer demand } \\
\text { for products }\end{array}$ & $\begin{array}{l}\text { Chieh-Yu Lin [29]; } \\
\text { Kilbourne and Beckmann [30] }\end{array}$ \\
\hline 7 & $\begin{array}{l}\text { Consciousness of } \\
\text { Senior Executives }\end{array}$ & $\begin{array}{l}\text { The consciousness of senior executives } \\
\text { to undertake EPR in the enterprise. }\end{array}$ & $\begin{array}{l}\text { Singh and Kant [31]; } \\
\text { Zhu and Sarkis [32]; } \\
\text { Allen et al. [33]. }\end{array}$ \\
\hline 8 & $\begin{array}{l}\text { Economic Benefit } \\
\text { of Recycling }\end{array}$ & $\begin{array}{l}\text { The economic benefit of end-of-life } \\
\text { (EOL) products obtained by recyclers. }\end{array}$ & $\begin{array}{l}\text { Stevels [34]; } \\
\text { Zhu and Sarkis [35]; } \\
\text { and Holt [36]; } \\
\text { Rao [37]; } \\
\text { Green et al. [38] }\end{array}$ \\
\hline 9 & $\begin{array}{l}\text { Technological Innovative } \\
\text { Ability of the Enterprise }\end{array}$ & $\begin{array}{l}\text { The capability of the enterprise to } \\
\text { achieve eco design and green } \\
\text { manufacturing. }\end{array}$ & Our contributed barrier \\
\hline 10 & $\begin{array}{l}\text { Environmental Hazard } \\
\text { of Products }\end{array}$ & $\begin{array}{l}\text { Negative influence on environment, } \\
\text { such as soil fertility, poisonous gases, } \\
\text { caused by EOL products. }\end{array}$ & $\begin{array}{l}\text { Shang et al. [39]; } \\
\text { Gutowski [40] }\end{array}$ \\
\hline 11 & Reverse Logistics Capability & $\begin{array}{l}\text { Reverse logistics is the one of the tools } \\
\text { to achieve EPR. }\end{array}$ & $\begin{array}{l}\text { Diabat \& Govindan [20], } \\
\text { Routroy [41], } \\
\text { Rao \& Holt [26], } \\
\text { Zhu et al. [24], } \\
\text { Hu \& Hsu [42] }\end{array}$ \\
\hline 12 & Corporate Image & $\begin{array}{l}\text { Being more responsible to the social and } \\
\text { environmental impact helps to enhance } \\
\text { the enterprise's image. }\end{array}$ & $\begin{array}{l}\text { Chen [43]; } \\
\text { Zhu et al. [32] }\end{array}$ \\
\hline
\end{tabular}




\section{Methodology}

\subsection{ISM}

ISM is a multi-criteria decision-making tool that identifies the relationships amongst various elements and presents a visualised hierarchical structure of a complex system or a field of study. ISM decomposes a complicated system into several subsystems (elements) and constructs a multi-level structural model based on the practical experience and knowledge of experts (Warfield [44]; Sage [45]; Mandal and Deshmukh [46]; Jharkharia and Shankar [47]). In management research, ISM has been extensively applied in supplier selection and policy analysis. This study adopts ISM to analyse the hierarchical relationships amongst the driving factors of EPR.

The steps involved in ISM are as follows:

Step 1: The alternatives (criteria) that drive EPR implementation are identified.

Step 2: A contextual relationship is established based on the drivers identified in Step 1.

Step 3: A structural self-interaction matrix (SSIM) is developed for drivers; it indicates the pairwise relationships amongst the drivers in the system under consideration.

Step 4: A reachability matrix is developed from SSIM and checked for transitivity.

Step 5: The reachability matrix in Step 4 is partitioned into different levels.

Step 6: A directed graph is drawn based on the abovementioned relationship, and transitive links are removed.

Step 7: The resultant digraph is converted into an ISM by replacing variable nodes with statements.

Step 8: The ISM model developed in Step 7 is reviewed to check for conceptual inconsistencies and necessary modifications.

These steps are illustrated in Figure 1.

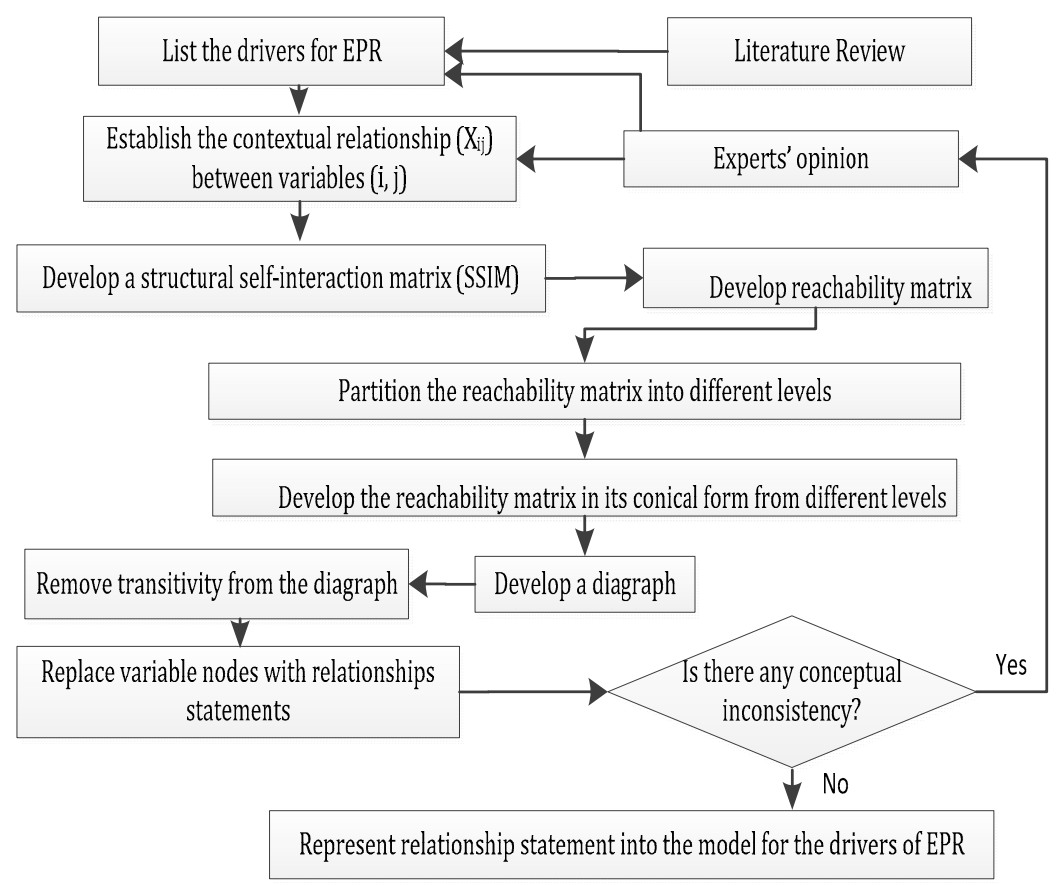

Figure 1. Flow diagram for preparing Interpretative Structure Modelling) (modified from Kannan et al. [48]).

\subsection{ANP}

ANP is a generalisation of the analytic hierarchy process; it is a comprehensive decision-making technique that considers the dependence amongst the elements of a hierarchy and determines the interrelationships amongst the decision variables to prioritise various alternatives (Saaty $[49,50])$. 
The priorities are obtained through ratio-scale and pairwise comparisons of elements. A supermatrix is required as an ANP input in determining factor weights. A supermatrix is a collection of matrices formed from eigen vectors, in which each matrix fragment expresses a relationship between two clusters in a system (Meade and Sarkis [51]).

The steps involved in the ANP methodology are as follows (Saaty [49]):

Step 1: The decision problem, including its objectives, criteria and subcriteria, actors and their objectives, and the possible outcomes of that decision, is elucidated.

Step 2: Several pairwise comparisons are conducted to establish the relative importance of determinants in achieving the objective.

Step 3: The relative importance of each dimension for a determinant is obtained through a pairwise comparison matrix.

Step 4: Pairwise comparison of elements at each level is conducted with respect to their relative influence towards their control criterion.

Step 5: Pairwise comparisons are performed to determine interdependencies amongst the enablers.

Step 6: A final set of pairwise comparisons is performed for the relative effect of each of the outsourcing alternatives on the enablers in influencing the determinants.

Step 7: A computation is performed for the supermatrix.

Step 8: The limiting priorities are synthesised by weighting each idealised limit vector by the weight of its control criterion and adding the resulting vectors.

\section{Problem Description and Data Collection}

In EPR implementation, the manufacturer plays an important role in the reverse supply chain it participates in. The manufacturer is responsible for collecting, recycling (remanufacturing), reprocessing, and other operations of the reverse supply chain of EOL products. Therefore, from the perspective of enterprise management, EPR implementation means a systematic change in the production and operation system of a company. It is one of the critical strategic decisions made by managers in enterprises. Manufacturers implement EPR for various purposes and under different forms of pressure. In other words, several drivers (or enablers) enhance the impetus of decision makers to implement EPR, and the possibility of manufacturers implementing EPR improves accordingly. For policy makers to guarantee the economic and environmental benefits of social unity, governments need to explore the drivers of the EPR implementation of enterprises and adopt the most efficient measures to improve the driving effect.

\subsection{Factor Recognition}

An expert committee composed of 10 professional experts in the manufacturing industry was established to identify the driving factors of EPR implementation. These experts have industrial and academic experiences in the reverse supply chain in the manufacturing industry, 5 of them are scholars in universities, and the other 5 are managers of electronics industry in China. Aside from the opinions of the expert committee, several academic studies focusing on related topics were also used as references (Step 1). Twelve driving factors of EPR were determined based on the review of extant literature and consultation with the committee (Table 1).

\subsection{Data Collection}

After the identification of the driving factors, the expert group explored the inter-relationships amongst the factors. ISM supports the use of expert opinions obtained through various management techniques, such as brainstorming and nominal technique, in developing the contextual relationship amongst the variables (Step 2). The expert committee discussed the contextual relationship amongst the 12 factors until an agreement was made. The final agreement was presented in the form of SSIM, which is elucidated in Section 5. 


\section{Partition Analysis of Driving Factors by Using ISM}

The driving factors of EPR were identified in the previous section, and the relationships amongst them were also determined. The current section explores the driving factors of EPR through ISM, which can identify and sum up the relationships amongst items to define an issue.

The analysis process of ISM is as follows.

\subsection{SSIM}

As described in Section 4.2, the relationships amongst the proposed driving factors of EPR were developed based on the results of the discussion of the expert committee. The consensus result was obtained through SSIM according to the inter-relationships identified by the expert committee (Step 3). In the self-interaction matrix, the meanings of the four symbols are as follows:

V: Element $i$ helps in achieving Element $j$;

A: Element $j$ helps in achieving Element $i$;

$X$ : Elements $i$ and $j$ help in achieving each other;

$\mathrm{O}$ : Elements $i$ and $j$ are unrelated.

The pairwise relationships amongst the 12 driving factors are shown as SSIM in Table 2.

Table 2. Structural self-interaction matrix (SSIM).

\begin{tabular}{cccccccccccc}
\hline & $\mathbf{1 2}$ & $\mathbf{1 1}$ & $\mathbf{1 0}$ & $\mathbf{9}$ & $\mathbf{8}$ & $\mathbf{7}$ & $\mathbf{6}$ & $\mathbf{5}$ & $\mathbf{4}$ & $\mathbf{3}$ & $\mathbf{2}$ \\
\hline 1 & $\mathrm{O}$ & $\mathrm{V}$ & $\mathrm{O}$ & $\mathrm{X}$ & $\mathrm{O}$ & $\mathrm{V}$ & $\mathrm{O}$ & $\mathrm{V}$ & $\mathrm{V}$ & $\mathrm{V}$ & $\mathrm{V}$ \\
2 & $\mathrm{O}$ & $\mathrm{O}$ & $\mathrm{O}$ & $\mathrm{O}$ & $\mathrm{A}$ & $\mathrm{V}$ & $\mathrm{X}$ & $\mathrm{A}$ & $\mathrm{O}$ & $\mathrm{O}$ & \\
3 & $\mathrm{O}$ & $\mathrm{O}$ & $\mathrm{A}$ & $\mathrm{O}$ & $\mathrm{X}$ & $\mathrm{V}$ & $\mathrm{O}$ & $\mathrm{V}$ & $\mathrm{V}$ & & \\
4 & $\mathrm{O}$ & $\mathrm{O}$ & $\mathrm{O}$ & $\mathrm{O}$ & $\mathrm{O}$ & $\mathrm{V}$ & $\mathrm{O}$ & $\mathrm{X}$ & & & \\
5 & $\mathrm{~V}$ & $\mathrm{X}$ & $\mathrm{A}$ & $\mathrm{O}$ & $\mathrm{A}$ & $\mathrm{V}$ & $\mathrm{V}$ & & & & \\
6 & O & A & O & A & A & V & & & & & \\
7 & X & A & O & A & A & & & & & & \\
8 & O & V & A & O & & & & & & & \\
9 & V & O & X & & & & & & & & \\
10 & V & O & & & & & & & & & \\
11 & V & & & & & & & & & & \\
\hline
\end{tabular}

\subsection{Initial Reachability Matrix}

According to the methodology of ISM, the initial reachability matrix was derived from the obtained SSIM. The SSIM for the drivers in EPR implementation is presented in Table 2. The initial reachability matrix was obtained by transforming $\mathrm{X}, \mathrm{A}, \mathrm{V}$, and $\mathrm{O}$ into 0 and 1 according to the SSIM in Table 2. The following lines explain the meaning of the symbols $\mathrm{V}, \mathrm{A}, \mathrm{X}$, and $\mathrm{O}$ in the SSIM.

If an entry in the cell $(i, j)$ in the SSIM is $\mathrm{V}$, then $c_{i, j}=1$ and $c_{i, j}=0$ in the initial reachability matrix. If an entry in the cell $(i, j)$ in the SSIM is $\mathrm{A}$, then $c_{i, j}=0$ and $c_{i, j}=1$ in the initial reachability matrix. If an entry in the cell $(i, j)$ in the SSIM is $\mathrm{X}$, then $c_{i, j}=1$ and $c_{i, j}=1$ in the initial reachability matrix If an entry in the cell $(i, j)$ in the SSIM is $\mathrm{O}$, then $c_{i, j}=0$ and $c_{i, j}=0$ in the initial reachability matrix.

The initial reachability matrix is presented in Table 3.

The transitivity of the contextual relation is a basic assumption in ISM. If variable $\mathrm{A}$ is related to $B$, and $B$ is related to $C$, then $A$ is necessarily related to $C$. The transitivity property was verified according to this assumption (Step 4), and the final reachability matrix is shown in Table 4 . In the final reachability matrix, the calculated driver power and dependence power of each element are provided in the last row and column, respectively. 
Table 3. Initial Reachability Matrix.

\begin{tabular}{ccccccccccccc}
\hline & $\mathbf{1}$ & $\mathbf{2}$ & $\mathbf{3}$ & $\mathbf{4}$ & $\mathbf{5}$ & $\mathbf{6}$ & $\mathbf{7}$ & $\mathbf{8}$ & $\mathbf{9}$ & $\mathbf{1 0}$ & $\mathbf{1 1}$ & $\mathbf{1 2}$ \\
\hline 1 & 1 & 1 & 1 & 1 & 1 & 0 & 1 & 0 & 1 & 0 & 1 & 0 \\
2 & 0 & 1 & 0 & 0 & 0 & 1 & 1 & 0 & 0 & 0 & 0 & 0 \\
3 & 0 & 0 & 1 & 1 & 0 & 0 & 1 & 1 & 0 & 0 & 0 & 0 \\
4 & 0 & 0 & 0 & 1 & 1 & 0 & 1 & 0 & 0 & 0 & 0 & 0 \\
5 & 0 & 1 & 0 & 1 & 1 & 1 & 1 & 0 & 0 & 0 & 1 & 1 \\
6 & 0 & 1 & 0 & 0 & 0 & 1 & 1 & 0 & 0 & 0 & 0 & 0 \\
7 & 0 & 0 & 0 & 0 & 0 & 0 & 1 & 0 & 0 & 0 & 0 & 1 \\
8 & 0 & 1 & 1 & 0 & 1 & 1 & 1 & 0 & 0 & 0 & 1 & 0 \\
9 & 1 & 0 & 0 & 0 & 0 & 1 & 1 & 1 & 1 & 1 & 0 & 0 \\
10 & 0 & 0 & 1 & 0 & 1 & 0 & 0 & 1 & 1 & 1 & 0 & 1 \\
11 & 0 & 0 & 0 & 0 & 1 & 1 & 1 & 0 & 0 & 0 & 1 & 1 \\
12 & 0 & 0 & 0 & 0 & 0 & 0 & 1 & 0 & 0 & 0 & 0 & 1 \\
\hline
\end{tabular}

Table 4. Final Reachability Matrix.

\begin{tabular}{ccccccccccccccc}
\hline & $\mathbf{1}$ & $\mathbf{2}$ & $\mathbf{3}$ & $\mathbf{4}$ & $\mathbf{5}$ & $\mathbf{6}$ & $\mathbf{7}$ & $\mathbf{8}$ & $\mathbf{9}$ & $\mathbf{1 0}$ & $\mathbf{1 1}$ & $\mathbf{1 2}$ & DriverPower \\
\hline 1 & 1 & 1 & 1 & 1 & 1 & 1 & 1 & 1 & 1 & 1 & 1 & 1 & 12 \\
2 & 0 & 1 & 0 & 0 & 0 & 1 & 1 & 0 & 0 & 0 & 0 & 1 & 4 \\
3 & 0 & 1 & 1 & 1 & 1 & 1 & 1 & 1 & 0 & 0 & 1 & 1 & 9 \\
4 & 0 & 1 & 0 & 1 & 1 & 1 & 1 & 0 & 0 & 0 & 1 & 1 & 7 \\
5 & 0 & 1 & 0 & 1 & 1 & 1 & 1 & 0 & 0 & 0 & 1 & 1 & 7 \\
6 & 0 & 1 & 0 & 0 & 0 & 1 & 1 & 0 & 0 & 0 & 0 & 1 & 4 & 9 \\
7 & 0 & 0 & 0 & 0 & 0 & 0 & 1 & 0 & 0 & 0 & 0 & 1 & 2 \\
8 & 0 & 1 & 1 & 1 & 1 & 1 & 1 & 1 & 0 & 0 & 1 & 1 & & 9 \\
9 & 1 & 1 & 1 & 1 & 1 & 1 & 1 & 1 & 1 & 1 & 1 & 1 & & 12 \\
10 & 1 & 1 & 1 & 1 & 1 & 1 & 1 & 1 & 1 & 1 & 1 & 1 & 12 \\
11 & 0 & 1 & 0 & 1 & 1 & 1 & 1 & 0 & 0 & 0 & 1 & 1 & & 7 \\
12 & 0 & 0 & 0 & 0 & 0 & 0 & 1 & 0 & 0 & 0 & 0 & 1 & 2 \\
\hline Dependence Power & 3 & 10 & 5 & 8 & 8 & 10 & 12 & 5 & 3 & 3 & 8 & 12 &
\end{tabular}

\subsection{Level Partitions}

The final reachability matrix demonstrates that reachability and antecedent sets can be obtained (Step 5), as shown in Table 5. The procedure and corresponding rules of level partitions are summarised as follows.

(1) Identifying the reachability and antecedent sets

The reachability and antecedent sets can be obtained from the reachability matrix. The reachability set of Element $\mathrm{Si}$ consists of the elements influenced by $\mathrm{Si}$, including Element $\mathrm{Si}$ itself. The antecedent set of Element $\mathrm{Si}$ consists of the elements that influence $\mathrm{Si}$, including Element $\mathrm{Si}$ itself as well.

(2) Separating the top-level element

The reachability and antecedent sets of all elements are listed according to the first rule, and the intersection of the two sets of each element is analysed. The elements with the same reachability and intersection sets, i.e., $R(\mathrm{Si}) \cap A(\mathrm{Si})=R(\mathrm{Si})$, are considered top-level elements. As shown in Table 5, D7 and D12 are top-level elements of the ISM digraph. Under this principle, these two elements must be discarded in the following analysis.

(3) Exploring elements in the following levels

The obtained top-level elements need to be eliminated accordingly in the following analysis, and similar processes need to be performed sequentially. This process continues until the last element is identified. 
The levels and corresponding sets of each element are presented in Table 5.

Table 5. Levels of Criteria.

\begin{tabular}{|c|c|c|c|c|}
\hline Criteria & $\begin{array}{l}\text { Reachability Set } \\
\qquad R\left(S_{\mathrm{i}}\right)\end{array}$ & $\begin{array}{c}\text { Antecedent Set } \\
\qquad A\left(S_{\mathrm{i}}\right)\end{array}$ & $\begin{array}{c}\text { Intersection Set } \\
R\left(S_{\mathrm{i}}\right) \cap A\left(S_{\mathrm{i}}\right)\end{array}$ & Level \\
\hline S7 & S7, S12 & $\mathrm{S} 1, \mathrm{~S} 2, \mathrm{~S} 3, \mathrm{~S} 4, \mathrm{~S} 5, \mathrm{~S} 6, \mathrm{~S} 7, \mathrm{~S} 8, \mathrm{~S} 9, \mathrm{~S} 10, \mathrm{~S} 11, \mathrm{~S} 12$ & $\mathrm{~S} 7, \mathrm{~S} 12$ & I \\
\hline S12 & $\mathrm{S} 7, \mathrm{~S} 12$ & $\mathrm{~S} 1, \mathrm{~S} 2, \mathrm{~S} 3, \mathrm{~S} 4, \mathrm{~S} 5, \mathrm{~S} 6, \mathrm{~S} 7, \mathrm{~S} 8, \mathrm{~S} 9, \mathrm{~S} 10, \mathrm{~S} 11, \mathrm{~S} 12$ & $\mathrm{~S} 7, \mathrm{~S} 12$ & I \\
\hline $\mathrm{S} 2$ & $\mathrm{~S} 2, \mathrm{~S} 6$ & $\mathrm{~S} 1, \mathrm{~S} 2, \mathrm{~S} 3, \mathrm{~S} 4, \mathrm{~S} 5, \mathrm{~S} 6, \mathrm{~S} 8, \mathrm{~S} 9, \mathrm{~S} 10, \mathrm{~S} 11$ & S2, S6 & II \\
\hline S6 & $\mathrm{S} 2, \mathrm{~S} 6$ & $\mathrm{~S} 1, \mathrm{~S} 2, \mathrm{~S} 3, \mathrm{~S} 4, \mathrm{~S} 5, \mathrm{~S} 6, \mathrm{~S} 8, \mathrm{~S} 9, \mathrm{~S} 10, \mathrm{~S} 11$ & S2, S6 & II \\
\hline S4 & S4, S5, S11 & S1, S3, S4, S5, S8, S9, S10, S11 & S4, S5, S11 & III \\
\hline S5 & S4, S5, S11 & S1, S3, S4, S5, S8, S9, S10, S11 & S4, S5, S11 & III \\
\hline S11 & S4, S5, S11 & $\mathrm{S} 1, \mathrm{~S} 3, \mathrm{~S} 4, \mathrm{~S} 5, \mathrm{~S} 8, \mathrm{~S} 9, \mathrm{~S} 10, \mathrm{~S} 11$ & S4, S5, S11 & III \\
\hline S3 & S3, S8 & $\mathrm{S} 1, \mathrm{~S} 3, \mathrm{~S} 8, \mathrm{~S} 9, \mathrm{~S} 10$ & S3, S8 & IV \\
\hline S8 & S3, S8 & $\mathrm{S} 1, \mathrm{~S} 3, \mathrm{~S} 8, \mathrm{~S} 9, \mathrm{~S} 10$ & S3, S8 & IV \\
\hline S1 & $\mathrm{S} 1, \mathrm{~S} 9, \mathrm{~S} 10$ & $\mathrm{~S} 1, \mathrm{~S} 9, \mathrm{~S} 10$ & $\mathrm{~S} 1, \mathrm{~S} 9, \mathrm{~S} 10$ & $\mathrm{~V}$ \\
\hline S9 & $\mathrm{S} 1, \mathrm{~S} 9, \mathrm{~S} 10$ & $\mathrm{~S} 1, \mathrm{~S} 9, \mathrm{~S} 10$ & $\mathrm{~S} 1, \mathrm{~S} 9, \mathrm{~S} 10$ & $\mathrm{~V}$ \\
\hline S10 & S1, S9, S10 & S1, S9, S10 & $\mathrm{S} 1, \mathrm{~S} 9, \mathrm{~S} 10$ & $\mathrm{~V}$ \\
\hline
\end{tabular}

\subsection{Formation of the ISM-Based Model}

The hierarchical relationships of the driving factors of EPR were obtained based on the steps presented. ISM can be represented by Figure 2 by following the level partitions of driving factors (Table 5) and the final reachability matrix (Table 4). The existence and direction of the arrow between Elements $i$ and $j$ are determined by the relationship between them (Step 6). The ISM graph is shown in Figure 2.

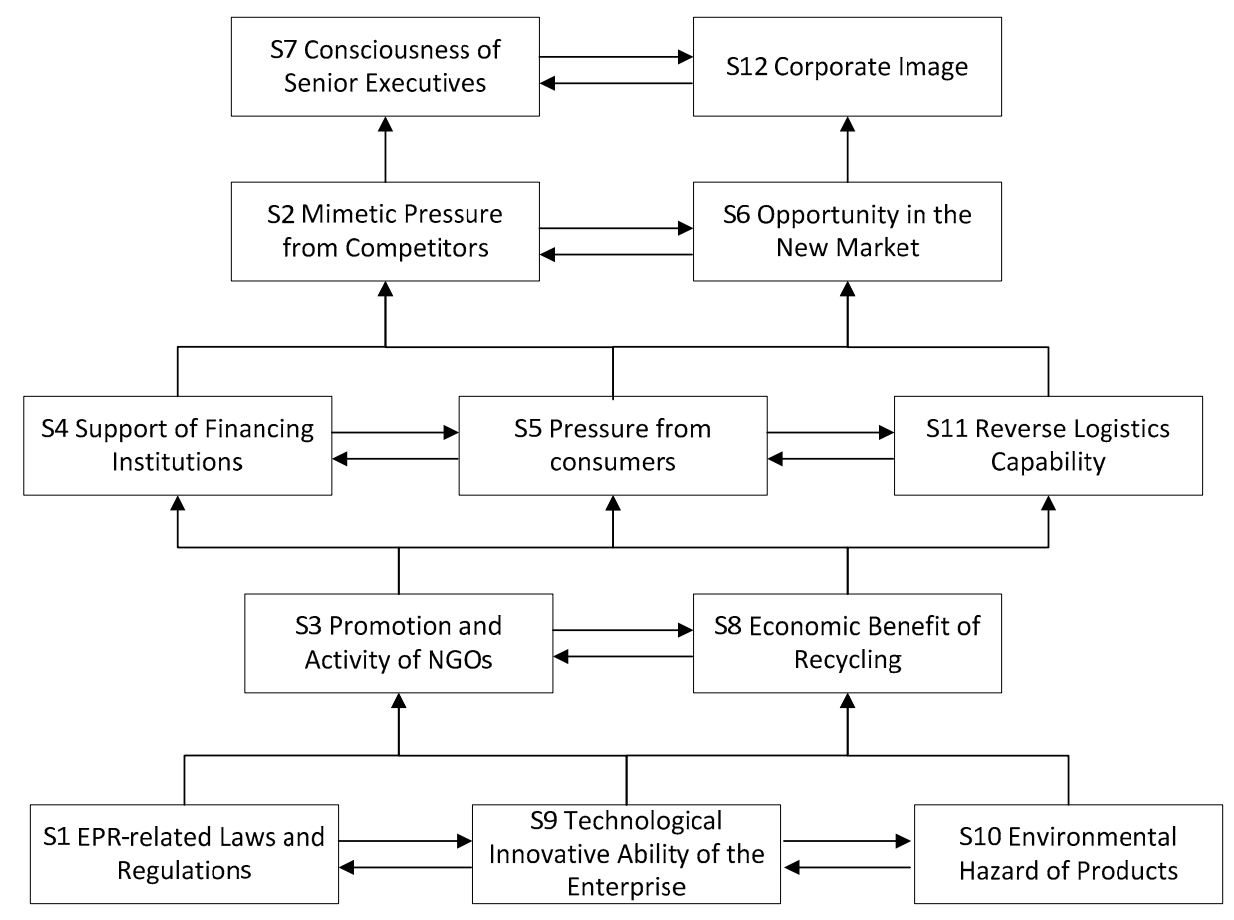

Figure 2. ISM digraph for drivers.

The ISM results have to be validated by academic experts and industrial managers. The feedback from experts and managers are generally positive in this study. The ISM rule implies that if several queries or loopholes exist in the ultimate results, then the entire analysis process should be implemented for a second time. In addition, the results of the ISM have to be validated by both academic experts and industrial managers. In the current study, the feedback from the experts and managers are generally positive. Therefore, the results of the ISM in our paper are valid (Step 7). 


\subsection{Matrix Cross-Reference Multiplication Applied to a Classification (MICMAC) Analysis}

MICMAC analysis was applied to examine the driving power and dependence power of drivers. The key drivers that drive the system were classified into various categories. Their driving power and dependence power indicated that the factors can be divided into four clusters (Kannan et al. [48]) based on the last row and column of the final reachability matrix (shown as Table 4 . The four clusters are autonomous, dependent, linkage, and independent factors. The driving power-dependence matrix is presented in Figure 3.

(1) Autonomous drivers have weak driving power and dependence power and are thus relatively irrelevant to the system. No autonomous variable is present in this model. These drivers are presented in Quadrant I.

(2) Dependent drivers always have weak driving power and strong dependence power. Elements S2, S6, S7, and S12 are strongly dependent on other factors. Dependent factors always appear on the top of the ISM digraph. These drivers are presented in Quadrant II.

(3) Linkage drivers have strong driving power and strong dependence power. S4, S5, and S11 fall into the linkage area and are critical in EPR implementation. Linkage factors exert a relatively strong influence on the ultimate goal, and they have a feedback effect on themselves as well. These drivers are presented in Quadrant III.

(4) Independent drivers have strong driving power but weak dependence power. Elements S1, S3, S8, S9, and S10 are independent variables in the driving factor analysis of EPR. Independent factors always appear at the bottom of the ISM digraph. These factors are presented in Quadrant IV.

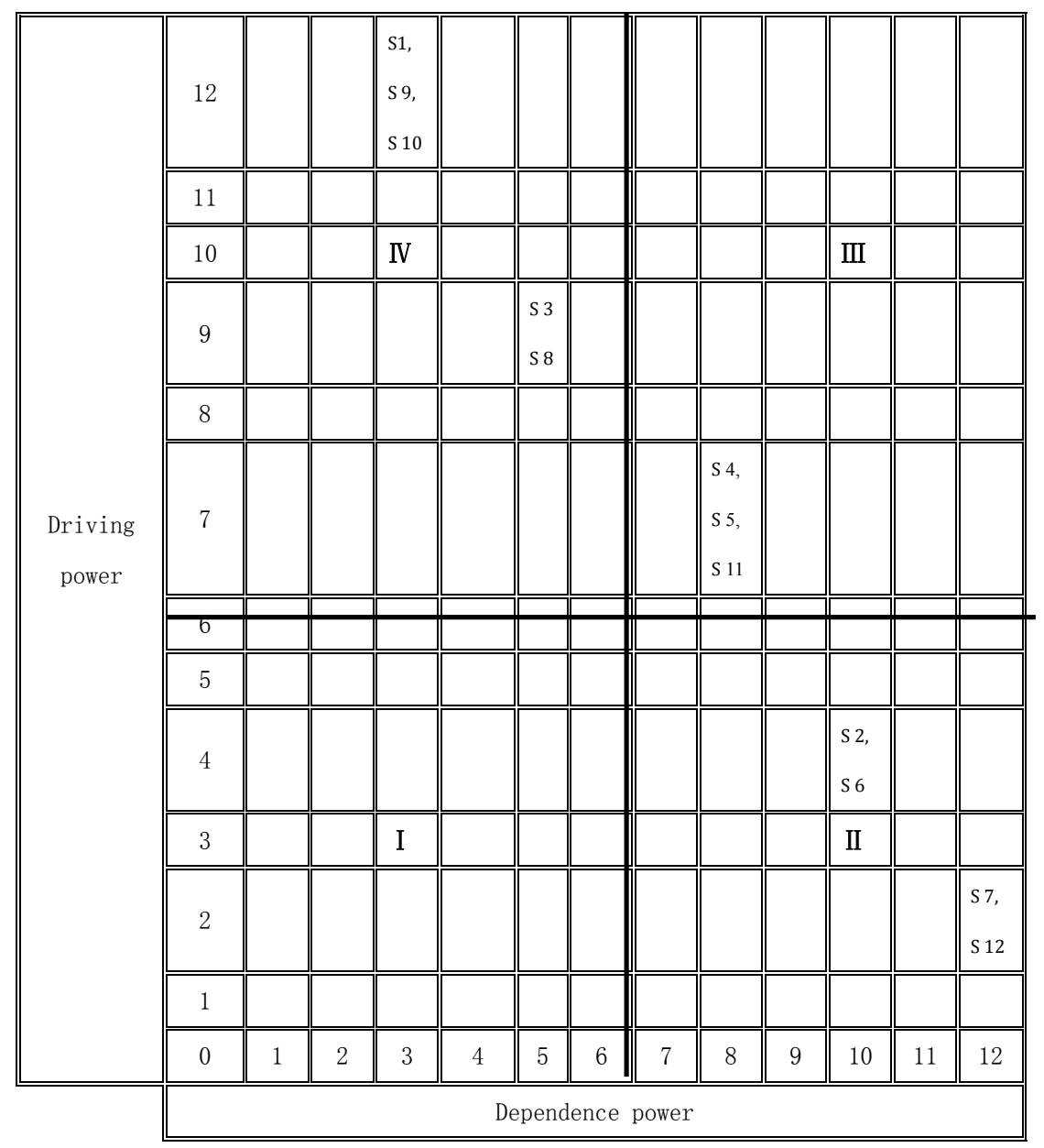

Figure 3. Driving power and dependence power diagram. 
Following the results of the ISM and MICMAC analysis, EPR-related Laws and Regulations (S1), Promotion and Activity of NGOs (S3), Economic Benefit of Recycling (S8), Technological Innovative Ability of the Enterprise (S9), and Environmental Hazard of Products (S10) are the most influential driving factors of the implementation of EPR. These five driving factors are divided into two layers, and Elements S1, S9, and S10 are regarded as 'key factors' which are at the bottom of the hierarchical structure and influence the other driving factors. For manufacturers and governments, starting off with these points to implement EPR is considered critical.

Support of financing institution (S4), pressure from consumers (S5) and reverse logistics capability (S11), are linkage drivers which have strong driving power and strong dependence power. For financing institutions, these factors significantly help in driving EPR implementation by offering green economy-related financial derivatives and green loans. Support from the point of finance and capital is provided for manufacturers who attempt to implement EPR. Consumer preference for products whose manufacturers assume the post-consumption responsibility is also an important driving factor in EPR implementation. A manufacturer who possesses a well-developed reverse logistics system is likely to implement EPR. The main reason is that a reverse logistics system saves operation cost during EPR implementation.

\section{Factor Ranking through ANP}

In the previous sections, the relationships and hierarchy of the driving factors were analysed through ISM. However, the sequence of importance of these driving factors cannot be presented by ISM. The current section ranks the driving factors of EPR through ANP. The 12 driving factors were divided into four clusters in terms of their types. The four clusters are law and regulation pressure, stakeholder factors, features of enterprises, and economic factors. The proposed ANP hierarchical structure is shown in Figure 4.

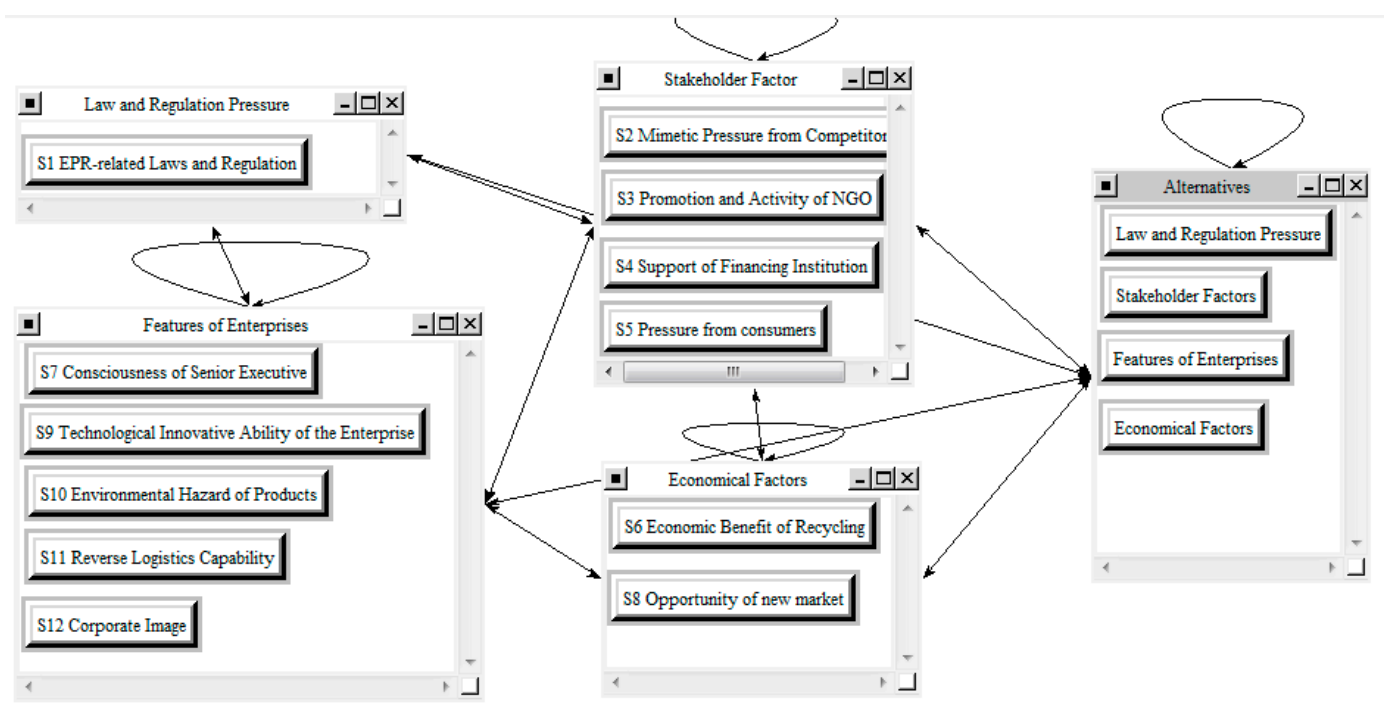

Figure 4. Clusters and nodes of the model.

The inter-relationships amongst the 12 driving factors were utilised as inputs in the ANP analysis. Pairwise comparisons of these 12 factors were conducted by an expert committee, which consists of five professional experts in the manufacturing industry. Each expert accomplished the questionnaire which adopts Saaty's nine-point scale. The final consensus was reached eventually after the discussion of the expert committee.

In this research, ANP analysis was completed with the Super Decisions software. The processing result of the weighted supermatrix is shown in Table 6. 
Table 6. Weighted Supermatrix.

\begin{tabular}{|c|c|c|c|c|c|c|c|c|c|c|c|c|c|c|c|c|c|}
\hline & Goal & D1 & D2 & D3 & D4 & S1 & S2 & S3 & S4 & S5 & S6 & S7 & S8 & S9 & S10 & S11 & $\mathrm{S} 12$ \\
\hline \multicolumn{18}{|l|}{ Goal } \\
\hline D1 & 0.534 & & 0.307 & 0.357 & 0.322 & & & & & & & & & & & & \\
\hline D2 & 0.088 & 0.066 & & 0.071 & 0.043 & & & & & & & & & & & & \\
\hline D3 & 0.288 & 0.330 & 0.134 & & 0.135 & & & & & & & & & & & & \\
\hline D4 & 0.090 & 0.104 & 0.059 & 0.071 & & & & & & & & & & & & & \\
\hline S1 & & 0.500 & & & & & & & & & & & & 0.712 & 0.688 & & \\
\hline S2 & & & 0.192 & & & 0.043 & & & & 0.038 & 0.277 & & 0.010 & & & & \\
\hline S3 & & & 0.044 & & & 0.016 & & & & & & & 0.008 & & 0.004 & & \\
\hline S4 & & & 0.071 & & & 0.030 & & 0.057 & & 0.019 & & & & & & & \\
\hline S5 & & & 0.192 & & & 0.155 & & & 0.225 & & & & 0.050 & & 0.029 & 0.108 & \\
\hline S6 & & & & 0.250 & & & 0.790 & & & 0.745 & & & 0.758 & 0.113 & & 0.702 & \\
\hline S7 & & & & & 0.152 & 0.486 & 0.210 & 0.198 & 0.775 & 0.071 & 0.723 & & 0.146 & 0.051 & & 0.095 & \\
\hline S8 & & & & 0.250 & & & & 0.745 & & & & & & 0.113 & 0.219 & & \\
\hline S9 & & & & & 0.033 & 0.049 & & & & & & & & & 0.007 & & \\
\hline S10 & & & & & 0.179 & & & & & 0.111 & & 1.000 & & & 0.052 & 0.095 & \\
\hline S11 & & & & & 0.090 & 0.073 & & & & 0.015 & & & 0.029 & & & & \\
\hline S12 & & & & & 0.179 & & & & & 0.111 & & 1.000 & & & 0.052 & 0.095 & \\
\hline
\end{tabular}


The priorities of the four dimensions were obtained from the processing results as follows: $\mathrm{D} 1=0.5339, \mathrm{D} 2=0.0877, \mathrm{D} 3=0.2881$, and D4 $=0.0903 . \mathrm{D} 1>\mathrm{D} 3>\mathrm{D} 4>\mathrm{D} 2$ can be inferred. In other words, law and regulation pressure (D1) is the most significant dimension in motivating enterprises to implement EPR.

The priorities of the driving factors in the four dimensions are listed in Table 7 . The sequence of factor priorities is $\mathrm{S} 1>\mathrm{S} 7>\mathrm{S} 12>\mathrm{S} 6>\mathrm{S} 2>\mathrm{S} 5>\mathrm{S} 8>\mathrm{S} 4>\mathrm{S} 3>\mathrm{S} 10=\mathrm{S} 11>\mathrm{S} 9$. This priority sequence implies that EPR-related laws and regulations (S1), consciousness of senior executives (S7) and corporate image (S12) are the three most significant driving factors in EPR implementation. The results show that laws and regulations have the most effective driving power in promoting EPR implementation. Consciousness of senior executives (S7) and corporate Image (S12) also play important roles in promoting EPR. In other words, enterprises whose senior executives realise the importance and obligation of EPR are willing to implement EPR in their commercial practice. Enterprises which have a good corporate image also always have the impetus to adopt EPR.

Table 7. Priorities of Driving Factors.

\begin{tabular}{cc}
\hline Name & Priorities \\
\hline S1 EPR-related Laws and Regulations & 0.534 \\
S2 Mimetic Pressure from Competitors & 0.04676 \\
S3 Promotion and Activity of NGOs & 0.00516 \\
S4 Support of Financing Institution & 0.00684 \\
S5 Pressure from Consumers & 0.02925 \\
S6 Opportunity of New Market & 0.07556 \\
S7 Consciousness of Senior Executives & 0.14448 \\
S8 Economic Benefit of Recycling & 0.01444 \\
S9 Technological Innovative Ability of the Enterprise & 0.00014 \\
S10 Environmental Hazard of Products & 0.00028 \\
S11 Reverse Logistics Capability & 0.00028 \\
S12 Corporate Image & 0.14282 \\
\hline
\end{tabular}

The result indicates that EPR-related laws and regulations play a key role in the establishment and development of EPR, which accounts for approximate 0.534 . In addition, consciousness of senior executives and corporate image has important effects on the establishment and development of EPR, which accounts for about 0.14448 and 0.14282 respectively. Obviously, the above results are intuitive and reasonable, and the reasons are that EPR-related laws and regulations directly and mandatorily enforce firms to take their responsibilities to recycle, refurbish, remanufacture, and dispose their products, which have a vital impact on firms' decisions and policies. Furthermore, if firms aim to shape good social images or senior executives have strong environmental consciousness, they are likely to carry out an EPR program and take some environmental and green actions. These results also provide support for why so many scholars focus on investigating the effects of governmental take-back legislations on companies' product recovery and remanufacturing strategies (e.g., Klausner and Hendrickson [52]; Webster and Mitra [53]; Atasu and Wassenhove [54]; Esenduran et al. [55,56]).

Except for these above three factors, we can observe that opportunities of new markets, mimetic pressure from competitors, pressure from consumers, and economic benefit of recycling are helpful to the implementation of EPR, which approximately account for 0.07556, 0.04676, 0.02925, and 0.01444 respectively. All of these factors can be summarized as economic incentives. Both chances to enter a new market, mimetic pressure from competitors, pressure from consumers, and economic benefit of recycling have a huge impact on production and inventory policies as well as market demand. Therefore, firms must take them into account in maximizing their long-term and short-term profit. Similarly, these discoveries help us explain why large numbers of scholars focus on exploring how collection cost structure, horizontal competitions, secondary market, and consumers green preference 
affect firms reverse logistics and remanufacturing policies (e.g., Oraiopoulos et al. [57]; Atasu et al. [58]; Chuang et al. [59]; Zhu and He [60]).

\section{Conclusions}

The establishment of efficient reverse supply chains in the manufacturing industry is important, especially in the electronics industry, because of the environmental and resource pressures worldwide. EPR is an effective environmental policy approach that has been extensively adopted in several countries. The effectiveness of its implementation has been proven through practical application. However, the establishment and development of EPR in most developing countries where collection and recycling systems are underdeveloped are lacking. This study addressed this problem by exploring the hierarchical relationship amongst the driving factors of EPR in the electronics industry in China and by identifying and ranking the factors that are critical in EPR implementation. The factors that are likely to encourage EPR performance were also identified. After identifying the driving factors and their hierarchical relationships, the incentive mechanism of EPR in the electronic industry, which helps stimulate EPR implementation amongst manufacturers, was obtained.

This study provides managerial implications for governments and manufacturers with regard to EPR implementation. For governments, the research findings provide a few guidelines on policymaking and system construction. Under EPR laws and regulations, manufacturers have to integrate the extended responsibility into their extant operation system. This paper presents the driving mechanism of EPR implementation in the electronics industry in China. Specifically, the consciousness of senior executives (S7) and corporate Image (S12) lay at the top level, which are the barriers that are affected by the lower factors and these barriers are comparatively easy to be influenced. There is comparatively less need to put much effort on improvement of these two factors. The second level includes two driving factors: Mimetic Pressure from Competitors (S2) and Opportunity of New Market (S6). The results show that EPR-related laws and regulation (S1), Technological Innovative Ability of the Enterprise (S9), and Environmental Hazard of Products (S10) are the three most significant driving factors of the implementation of EPR. Among these three factors which have obvious driving impact, Environmental Hazard of Products (S10) is determined by the type of the product, Technological Innovative Ability of the Enterprise (S9), Environmental Hazard of Products (S10) depend on the property of a company, and EPR-related Laws and Regulation (S1) is set by governments. The role of governments and policy makers should be to promote EPR implementation through appropriate laws and law enforcement. On the one hand, 'EPR-related Laws and Regulations', which is the bottom-level element of the ISM digraph, plays a fundamental role in driving EPR implementation. On the other hand, this element is the first priority in promoting EPR implementation. From the perspective of third-party organisations (financing institutions and e-NGOs), their support and promotion efforts help promote EPR implementation. The government can also provide these third-party organisations several financial or policy incentives for providing support to indirectly drive EPR implementation. Consumer factors also exert a driving effect, which means that the government and the society as a whole should exert considerable effort to promote the concept of EPR.

Every study, including the current one, possesses several limitations. The limitations of the current research are as follows. The expert committee consisted of 10 experts from industry and academia. However, the final results of their discussion and analysis are limited by the group size, and the results can be affected by their subjectivity. The same study can also be conducted in other areas, specifically in other developing countries, to explore the driving factors of EPR and analyse the dissimilarities between them. Structural equation modelling can also be adopted to quantitatively analyse the relationships identified through ISM. Structural Equation Modelling can also be adopted to quantitatively analyse these relationships, to obtain interrelationships among driving factors of EPR relying on data collected from enterprises. 
Author Contributions: Xiong Zheng identified the research problem; Xiong Zheng and Fangchao Xu designed the research and did the data analysis; Fangchao $\mathrm{Xu}$ and Lipan wrote the paper.

Conflicts of Interest: The authors declare no conflict of interest.

\section{References}

1. OECD Publishing. Extended Producer Responsibility: A Guidance Manual for Governments; Organisation for Economic Co-Operation and Development: Paris, France, 2001.

2. Manomaivibool, P. Extended producer responsibility in a non-OECD context: The management of waste electrical and electronic equipment in India. Resour. Conserv. Recycl. 2009, 53, 136-144. [CrossRef]

3. Lindhqvist, T. Extended Producer Responsibility in Cleaner Production: Policy Principle to Promote Environmental Improvements of Product Systems. Ph.D. Thesis, Lund University, Lund, Sweden, 1 January 2000.

4. Kibert, N.C. Extended producer responsibility: A tool for achieving sustainable development. J. Land Use Environ. Law 2004, 19, 503-523.

5. Lifset, R.; Atasu, A.; Tojo, N. Extended producer responsibility. J. Ind. Ecol. 2013, 17, 162-166. [CrossRef]

6. Kiddee, P.; Naidu, R.; Wong, M.H. Electronic waste management approaches: An overview. Waste Manag. 2013, 33, 1237-1250. [CrossRef] [PubMed]

7. OECD Publishing. Extended Producer Responsibility: Updated Guidance for Efficient Waste Management; OECD Publishing: Paris, France, 2016.

8. Nash, J.; Bosso, C. Extended producer responsibility in the United States. J. Ind. Ecol. 2013, 17, $175-185$. [CrossRef]

9. Kunz, N.; Atasu, A.; Mayers, K.; Wassenhove, L.V. Extended Producer Responsibility: Stakeholder Concerns and Future Developments; White Paper; INSEAD Social Innovation Centre: Fontainebleau, France, 2014.

10. Gui, L.; Atasu, A.; Ergun, Ö.; Toktay, L.B. Implementing extended producer responsibility legislation. J. Ind. Ecol. 2013, 17, 262-276. [CrossRef]

11. Wang, J.; Chen, M. Management status of end-of-life vehicles and development strategies of used automotive electronic control components recycling industry in China. Waste Manag. Res. J. Int. Solid Wastes Public Clean. Assoc. Iswa 2012, 30, 1198. [CrossRef] [PubMed]

12. Toffel, M.W. End-of-life product recovery: Drivers, prior research, and future directions. In Proceedings of the Conference on European Electronics Take-Back Legislation: Impacts on Business Strategy and Global Trade, Paris, France, 17-18 October 2002.

13. Zhao, Y.; Zhu, Q.; Wu, C. Empirical Study on the Effect of Implementing Extended Producer Responsibility (EPR) in China's Automobile Industry. Manag. Rev. 2008, 1, 006.

14. Gupt, Y.; Sahay, S. Review of extended producer responsibility: A case study approach. Waste Manag. Res. 2015, 33, 595-611. [CrossRef] [PubMed]

15. Wang, J.; Chen, M. Implementing extended producer responsibility: Vehicle remanufacturing in China. J. Clean. Prod. 2011, 19, 680-686.

16. Tong, X.; Lifset, R.; Lindhqvist, T. Extended Producer Responsibility in China. J. Ind. Ecol. 2005, 8, 6-9. [CrossRef]

17. Zhu, Q.; Sarkis, J. An inter-sectoral comparison of green supply chain management in China: Drivers and practices. J. Clean. Prod. 2006, 14, 472-486. [CrossRef]

18. AlKhidir, T.; Zailani, S. Going green in supply chain towards environmental sustainability. Glob. J. Environ. Res. 2009, 3, 246-251.

19. Wu, G.C.; Ding, J.H.; Chen, P.S. The effects of GSCM drivers and institutional pressures on GSCM practices in Taiwan's textile and apparel industry. Int. J. Prod. Econ. 2012, 135, 618-636. [CrossRef]

20. Diabat, A.; Govindan, K. An analysis of the drivers affecting the implementation of green supply chain management. Resour. Conserv. Recycl. 2011, 55, 659-667. [CrossRef]

21. Luo, J.; Chong, A.Y.L.; Ngai, E.W.T.; Liu, M.J. Green Supply Chain Collaboration implementation in China: The mediating role of guanxi. Trans. Res. Part E Logist. Trans. Rev. 2014, 71, 98-110. [CrossRef]

22. Lilly, M. Sustainable Manufacturing: Manufacturing for Sustainability; Manufacturing Skills Australia (MSA): North Sydney, Australia, 2008. 
23. Gutowski, T.; Murphy, C.; Allen, D.; Bauer, D.; Bras, B.; Piwonka, T.; Sheng, P.; Sutherland, J.; Thurston, D.; Wolff, E. Environmentally benign manufacturing: Observations from Japan, Europe and the United States. J. Clean. Prod. 2005, 13, 1-17. [CrossRef]

24. Zhu, Q.; Sarkis, J.; Geng, Y. Green supply chain management in China: Pressures, practices and performance. Int. J. Oper. Prod. Manag. 2005, 25, 449-468. [CrossRef]

25. Rehman, M.A.A.; Shrivastava, R.L. An innovative approach to evaluate green supply chain management (GSCM) drivers by using interpretive structural modeling (ISM). Int. J. Innov. Technol. Manag. 2011, 8, 315-336. [CrossRef]

26. Soo Wee, Y.; Quazi, H.A. Development and validation of critical factors of environmental management. Ind. Manag. Data Syst. 2005, 105, 96-114. [CrossRef]

27. Sarkis, J. How Green Is the Supply Chain? Practice and Research; Graduate School of Management, Clark University: Worchester, UK, 1999; pp. 1-40.

28. Berry, M.A.; Rondinelli, D.A. Proactive corporate environmental management: A new industrial revolution. Acad. Manag. Exec. 1998, 12, 38-50. [CrossRef]

29. Chien, M.K.; Shih, L.H. An empirical study of the implementation of green supply chain management practices in the electrical and electronic industry and their relation to organizational performances. Int. J. Environ. Sci. Technol. (IJEST) 2007, 4, 383.

30. Kilbourne, W.E.; Beckmann, S.C. Review and Critical Assessment of Research on Marketing and the Environment. J. Mark. Manag. 1998, 14, 513-532. [CrossRef]

31. Singh, M.D.; Kant, R. Knowledge management barriers: An interpretive structural modeling approach. Int. J. Manag. Sci. Eng. Manag. 2008, 3, 141-150.

32. Zhu, Q.; Sarkis, J. The moderating effects of institutional pressures on emergent green supply chain practices and performance. Int. J. Prod. Res. 2007, 45, 4333-4355. [CrossRef]

33. Allen, D.; Bauer, D.; Bras, B.; Gutowski, T.; Murphy, C.; Piwonka, T.; Sheng, P.; Sutherland, J.; Thurston, D.; Wolff, E. Environmentally Benign Manufacturing: Trends in Europe, Japan, and the USA. J. Manuf. Sci. Eng. 2002, 124, 908-920.

34. Stevels, A. Green Supply chain management, much more than questionnaires and ISO 14.001. In Proceedings of the IEEE International Symposium on Electronics and the Environment, San Francisco, CA, USA, 6-9 May 2002.

35. Zhu, Q.; Sarkis, J. Relationships between operational practices and performance among early adopters of green supply chain management practices in Chinese manufacturing enterprises. J. Oper. Manag. 2004, 22, 265-289. [CrossRef]

36. Rao, P.; Holt, D. Do green supply chains lead to competitiveness and economic performance? Int. J. Oper. Prod. Manag. 2005, 25, 898-916. [CrossRef]

37. Rao, P. Greening the supply chain: a new initiative in South East Asia. Int. J. Op. Prod. Manag. 2002, 22, 632-655. [CrossRef]

38. Green, K.; Morton, B.; New, S. Greening Organizations Purchasing, Consumption, and Innovation. Organ. Environ. 2000, 13, 206-225. [CrossRef]

39. Shang, K.C.; Lu, C.S.; Li, S. A taxonomy of green supply chain management capability among electronics-related manufacturing firms in Taiwan. J. Environ. Manag. 2010, 91, 1218-1226. [CrossRef] [PubMed]

40. Gutowski, T.G. Environmentally benign manufacturing and ecomaterials; Product induced material flows. Mater. Trans. 2002, 43, 359-363. [CrossRef]

41. Routroy, S. Antecedents and drivers for green supply chain management implementation in manufacturing environment. ICFAI J. Supply Chain Manag. 2009, 6, 20-35.

42. Hu, A.H.; Hsu, C.W. Empirical study in the critical factors of green supply chain management (GSCM) practice in the Taiwanese electrical and electronics industries. In Proceedings of the 2006 IEEE International Conference on Management of Innovation and Technology, Singapore, 21-23 June 2006.

43. Chen, Y.S. The Driver of Green Innovation and Green Image: Green Core Competence. J. Bus. Ethics 2008, 81, 531-543. [CrossRef]

44. Warfield, J.N. Developing subsystem matrices in structural modelling. IEEE Trans. Syst. Man Cybern. 1974, 1, 74-80. [CrossRef] 
45. Sage, A.P. Systems Engineering: Methodology \& Applications; IEEE Computer Society Press: Washington, DC, USA, 1977.

46. Mandal, A.; Deshmukh, S.G. Vendor selection using interpretive structural modelling (ISM). Int. J. Oper. Prod. Manag. 1994, 14, 52-59. [CrossRef]

47. Jharkharia, S.; Shankar, R. Selection of logistics service provider: An analytic network process (ANP) approach. Omega 2007, 35, 274-289. [CrossRef]

48. Kannan, G.; Pokharel, S.; Kumar, P.S. A hybrid approach using ISM and fuzzy TOPSIS for the selection of reverse logistics provider. Resour. Conserv. Recycl. 2009, 54, 28-36. [CrossRef]

49. Saaty, T.L. The Analytic Network Process; RWS Publications: Pittsburgh, PA, USA, 1996.

50. Saaty, T.L. Fundamentals of the Analytic Hierarchy Process. Available online: http:/ /link.springer.com/ chapter/10.1007\%2F978-94-015-9799-9_2\#page-1 (accessed on 28 March 2017).

51. Meade, L.M.; Sarkis, J. Analyzing organizational project alternatives for agile manufacturing processes: An analytical network approach. Int. J. Prod. Res. 1999, 37, 241-261. [CrossRef]

52. Klausner, M.; Hendrickson, C.T. Reverse-logistics strategy for product take-back. Interfaces 2000, 30, $156-165$. [CrossRef]

53. Webster, S.; Mitra, S. Competitive strategy in remanufacturing and the impact of take-back laws. J. Oper. Manag. 2007, 25, 1123-1140. [CrossRef]

54. Atasu, A.; Wassenhove, L.N. An Operations Perspective on Product Take-Back Legislation for E-Waste: Theory, Practice, and Research Needs. Prod. Oper. Manag. 2012, 21, 407-422. [CrossRef]

55. Esenduran, G.; Kemahlığlu-Ziya, E.; Swaminathan, J.M. Take-Back Legislation: Consequences for Remanufacturing and Environment. Decis. Sci. 2016, 47, 219-256. [CrossRef]

56. Esenduran, G.; Kemahlığlu-Ziya, E.; Swaminathan, J.M. Impact of Take-Back Regulation on the Remanufacturing Industry. Prod. Oper. Manag. 2017. [CrossRef]

57. Oraiopoulos, N.; Ferguson, M.E.; Toktay, L.B. Relicensing as a secondary market strategy. Manag. Sci. 2012, 58, 1022-1037. [CrossRef]

58. Atasu, A.; Toktay, L.B.; Van Wassenhove, L.N. How collection cost structure drives a manufacturer's reverse channel choice. Prod. Oper. Manag. 2013, 22, 1089-1102. [CrossRef]

59. Chuang, C.H.; Wang, C.X.; Zhao, Y. Closed-loop supply chain models for a high-tech product under alternative reverse channel and collection cost structures. Int. J. Prod. Econ. 2014, 156, 108-123. [CrossRef]

60. Zhu, W.; He, Y. Green product design in supply chains under competition. Eur. J. Oper. Res. 2017, 258, 165-180. [CrossRef]

(C) 2017 by the authors. Licensee MDPI, Basel, Switzerland. This article is an open access article distributed under the terms and conditions of the Creative Commons Attribution (CC BY) license (http:/ / creativecommons.org/licenses/by/4.0/). 